\title{
Genetic structure of coastal and inland populations of Spergularia media (L.) C. Presl (Caryophyllaceae) in Central Europe
}

\author{
Kathleen Prinz $\cdot$ Kurt Weising $\cdot$ Isabell Hensen
}

Received: 1 December 2009/Accepted: 18 June 2010/Published online: 2 July 2010

(c) The Author(s) 2010. This article is published with open access at Springerlink.com

\begin{abstract}
In Central Europe, salt-influenced habitats are restricted mainly to the coastlines of the North Sea and the Baltic Sea. The few natural inland salt sites suffer from size reduction and loss in biodiversity, while anthropogenic salt sites around potash mining dumps experienced recent and massive de novo colonization by numerous halophytes. Our study aimed to elucidate the general patterns of gene flow among coastal and inland salt habitats. We used amplified fragment length polymorphisms to assess the genetic diversity and genetic structure of 18 European populations of the halophyte Spergularia media (Caryophyllaceae), sampled from inland and coastal salt sites of Germany, the Netherlands, Denmark, Austria, France and Italy. Estimates of genetic diversity on the population level were generally low, especially within inland salt habitats. Analyses of molecular variance showed comparatively strong differentiation among populations. Multivariate ordination (principal coordinate analysis) and a NeighborNet analysis revealed four distinct groups of populations
\end{abstract}

Electronic supplementary material The online version of this article (doi:10.1007/s10592-010-0103-y) contains supplementary material, which is available to authorized users.

K. Prinz $(\bowtie)$

Forest Genetics and Forest Tree Breeding, Georg-August-

University Göttingen, Büsgen-Insitute, Büsgenweg 2,

37077 Göttingen, Germany

e-mail: kathleen.prinz@forst.uni-goettingen.de

K. Weising

Plant Molecular Systematics, University of Kassel,

Heinrich-Plett-Straße 40, 34109 Kassel, Germany

I. Hensen

Institute of Biology/Geobotany and Botanical Garden,

Martin-Luther-University Halle-Wittenberg, Am Kirchtor 1,

06108 Halle/Saale, Germany that showed good correspondence to their geographic origins. A Bayesian analysis performed with the program STRUCTURE as well as high pairwise $\Phi_{\mathrm{ST}}$ values supported the results of the phenetic analyses. The observed patterns of diversity and differentiation among inland populations of $S$. media are best explained by the isolated nature of suitable salt habitats, with concomitant reduction of gene flow to and among these sites. Our data support the hypothesis that the colonization of anthropogenic salt sites by $S$. media originated from natural inland habitats.

Keywords AFLP markers - Halophytes · Inland salt sites · Potash mining dumps · Genetic structure . Spergularia media

\section{Introduction}

Under the temperate and humid climatic conditions of Central Europe, salt-influenced habitats are largely restricted to a small strip of land along the coastlines of the North Sea and the Baltic Sea. These habitats are populated by highly specialized plant species that are able to survive under high-salt conditions in the soil, so-called halophytes. A few isolated salt sites also exist further inland, e.g., in the surroundings of natural salty springs. They usually accommodate a subset of the same halophytic species that are also found along the coasts. Because of their floristic peculiarity, Brandes (1999) referred to these inland salt sites as the "inselbergs of Central Europe". However, these remarkable habitats have become seriously endangered by species loss as well as by the ongoing reduction and fragmentation of their once larger areas (Westhus et al. 1997; Brandes 1999; Garve and Garve 2000). 
As a consequence of human potash mining activities since the middle of the nineteenth century, new salt-influenced inland habitats have developed in the immediate vicinity of the numerous Central European potash mining dumps. These purely anthropogenic habitats have been colonized by halophytes only recently, but then at a rapid pace (Guder et al. 1998; Garve 1999b; Garve and Garve 2000; John 2000). Presently, potash mining dumps are home to large populations of various halophytic species that are highly endangered or even in risk of extinction in their natural inland salt habitats. Some authors even considered anthropogenic salt sites as potential retreat areas that could serve as stepping stones for the (re)colonization of natural inland salt sites (Westhus et al. 1997; Krüger et al. 2002; Brock et al. 2007). However, halophyte communities at both types of inland salt habitat have probably experienced genetic drift, which is often accompanied by low levels of genetic diversity (Lienert 2004; Novak and Mack 2005; Prinz et al. 2009).

Floristics and vegetation of inland salt sites in Central Europe have been the subject of numerous publications (e.g., Vollrath and Bönsel 1995; Westhus et al. 1997; Guder et al. 1998; Garve 1999a, b; Garve and Garve 2000). However, still little is known about migration patterns and the timing of colonization of these sites by halophytic plants, and there is an ongoing controversial discussion on these issues. For example, Brandes (1999) postulated a continental or Mediterranean origin for Atriplex tatarica, Kochia densiflora, Gypsophila perfoliata, G. scorzonerifolia and Hymenolobus procumbens, whereas inland populations of Suaeda maritima, Salicornia ramosissima and Spergularia marina were assumed to originate from the coasts of the North Sea and the Baltic Sea. On the contrary, Garve (1999a) hypothesized that Suaeda maritima, Gypsophila scorzonerifolia and other halophytes currently found around mining dumps in Lower Saxony might have immigrated from other inland salt sites further east. Careful population genetic and biogeographic analyses could help to resolve these controversies. However, only a handful of studies so far addressed issues like genetic diversity, gene flow and genetic structure of coastal and inland halophyte populations by means of molecular markers (e.g., Krüger et al. 2002; Brock et al. 2007; Lambracht et al. 2007; Prinz et al. 2009).

Spergularia media (Caryophyllaceae) is a small perennial halophytic herb that grows on saline, mostly wet substrates in coastal and continental areas of western Eurasia (Hegi 1965). It is a common element of coastal salt meadows, but is also present around natural inland salt springs. The species was first recorded from the surroundings of potash mining dumps in the Alsace in the mid-1950s (Simon 1958), followed by records from BadenWürttemberg in 1978 (Plieninger 1992) and from Lower
Saxony, Hesse, Saxony-Anhalt and Thuringia in 1993 (Garve and Garve 2000). Presently, S. media is known from about $70 \%$ of all anthropogenic inland salt sites in Central Europe (Garve and Garve 2000). The species is usually pollinated by insects, but is also known to be selffertile. Its small, winged seeds are dispersed by wind, water or by attachment to animals (Hegi 1965; Huiskes et al. 1995).

We consider $S$. media to be a suitable model species for examining the biogeography and population genetics of halophytes at natural and anthropogenic inland salt sites of Central Europe. Here we present a genetic analysis based on amplified fragment length polymorphisms (AFLP, Vos et al. 1995) that addresses the following questions: (1) How is genetic variation distributed among and within populations of $S$. media, and is genetic diversity of inland populations lower as compared to that of coastal populations? (2) Can putative source populations of the anthropogenic inland salt sites be identified?

\section{Materials and methods}

\section{Plant material and DNA isolation}

Leaves of individual S. media plants were collected from 18 populations of different European coastal and inland habitats. About 15 plants per population were sampled in Germany and the Netherlands whereas populations from Austria, Denmark, France and Italy were represented by three to ten individuals per locality (Fig. 1, Table 1). Leaves were preserved and stored in $\mathrm{NaCl}$-saturated CTAB solution (cetyltrimethylammonium bromide; Rogstad 1992). DNA was extracted by a modified CTAB method (Doyle and Doyle 1987). Final DNA concentrations were determined electrophoretically, with known amounts of phage $\lambda$-DNA used as standard.

\section{AFLP analysis}

The AFLP protocol followed the method of Bänfer et al. (2004), with some modifications. Approximately $250 \mathrm{ng}$ of total genomic DNA were double-digested with HindIII and $\mathrm{Mse} \mathrm{I}$ at $37^{\circ} \mathrm{C}$ for $15 \mathrm{~h}$, and the resulting restriction fragments were ligated to HindIII and MseI adapters in the same reaction. The restriction/ligation assay contained 2.5 U each of HindIII and MseI enzyme, 0.1 U T4-DNA ligase, $0.01 \mu \mathrm{M}$ HindIII-adapter, $0.1 \mu \mathrm{M}$ MseI-adapter, $10 \mathrm{mM}$ Tris- $\mathrm{HCl}$ (pH 8.4), $10 \mathrm{mM}$ magnesium acetate, $50 \mathrm{mM}$ potassium acetate, $5 \mathrm{mM}$ DTT and $0.2 \mathrm{mM}$ ATP in a final volume of $30 \mu \mathrm{l}$. Five microliters of the restriction-ligation mixture were used as template for pre-selective PCR with two different combinations of primers, each containing one 


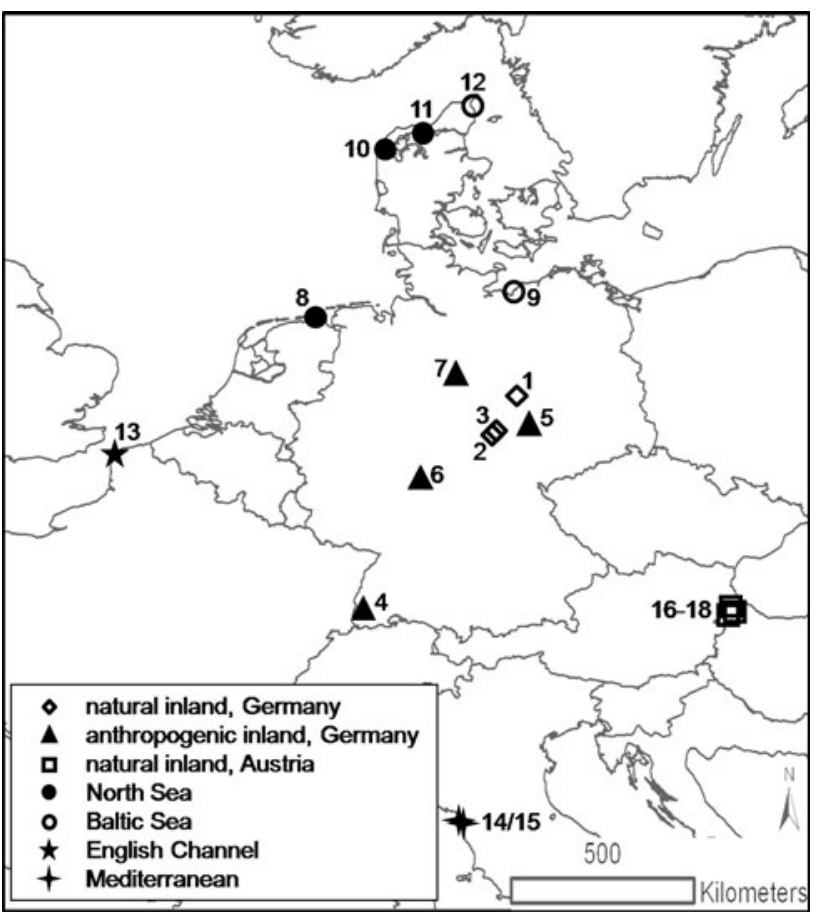

Fig. 1 Geographic origin of the studied S. media populations

selective nucleotide at its $3^{\prime}$-end $(0.3 \mu \mathrm{M}$ HindIII $+\mathrm{A}$ combined with $0.5 \mu \mathrm{M} \mathrm{MseI}+\mathrm{A}$ or $\mathrm{Mse} \mathrm{I}+\mathrm{C}$ primer). The reaction mix also contained $1.5 \mathrm{mM} \mathrm{MgCl} 2,0.2 \mathrm{mM}$ of each dNTP, $20 \mathrm{mM}$ Tris- $\mathrm{HCl}(\mathrm{pH} \mathrm{8.4),50} \mathrm{mM} \mathrm{KCl}$ and
$0.02 \mathrm{U}$ Taq DNA polymerase (Mango-Taq DNA-Polymerase, Bioline) in a total volume of $50 \mu \mathrm{l}$. Pre-selective PCR was performed in a T-Gradient Cycler (Biometra) under the following temperature regime: one cycle at $94^{\circ} \mathrm{C}$ for $2 \mathrm{~min}$, followed by 19 cycles at $94^{\circ} \mathrm{C}$ for $30 \mathrm{~s}, 60^{\circ} \mathrm{C}$ for $30 \mathrm{~s}$ and $72^{\circ} \mathrm{C}$ for $1 \mathrm{~min}$. Final extension was at $72^{\circ} \mathrm{C}$ for $7 \mathrm{~min}$. Selective PCRs were then performed with $2.5 \mu \mathrm{l}$ of a 1:10 diluted pre-amplification mixture and various combinations of an unlabeled $M s e \mathrm{I}+3$ primer $(0.6 \mu \mathrm{M})$ and a fluorescence-labeled HindIII +3 primer $\quad(0.075 \mu \mathrm{M}$ IRD700, $0.095 \mu \mathrm{M}$ IRD800; Table 2). Each $10 \mu$ l-assay also contained $0.3 \%$ Triton X-100, $0.1 \mathrm{mM} \mathrm{MgCl}_{2}$, $0.2 \mathrm{mM}$ of each dNTP, $20 \mathrm{mM}$ Tris- $\mathrm{HCl}$ (pH 8.4), $50 \mathrm{mM}$ $\mathrm{KCl}$ and $0.025 \mathrm{U}$ Taq DNA polymerase (Mango-Taq DNAPolymerase, Bioline). A touchdown PCR program was followed for 47 cycles, each consisting of $94^{\circ} \mathrm{C}$ for $30 \mathrm{~s}$, $65-56^{\circ} \mathrm{C}$ for $30 \mathrm{~s}$, and $72^{\circ} \mathrm{C}$ for $1 \mathrm{~min}$. Starting at $65^{\circ} \mathrm{C}$, the annealing temperature was reduced by $0.7^{\circ} \mathrm{C}$ in each cycle, and kept at $56^{\circ} \mathrm{C}$ for the last 35 cycles. Final extension was at $72^{\circ} \mathrm{C}$ for $6 \mathrm{~min}$.

AFLP products from two primer combinations labeled with different fluorescent dyes (IRD700, IRD800) were mixed with each other and with an equal volume of loading buffer containing $98 \%(\mathrm{v} / \mathrm{v})$ formamide, denatured at $80^{\circ} \mathrm{C}$ for $5 \mathrm{~min}$, and then separated by electrophoresis on denaturing 6\% polyacrylamide gels (Sequagel XR; National Diagnostics, Atlanta, Ga.). Gels were run in $1 \times$ TBE buffer (Tris-borate-EDTA) on an automated sequencer

Table 1 Geographic origin, type of habitat, and average gene diversity over all loci for the studied 18 populations of $S$. media

\begin{tabular}{|c|c|c|c|c|c|c|}
\hline Loc. no. & Sampling locality & Type of habitat & Country & Latitude/Longitude & $N$ & Gene diversity \\
\hline 1 & Sülldorf & Natural inland & C Germany & $52^{\circ} 01.65^{\prime} \mathrm{N} / 11^{\circ} 33.97^{\prime} \mathrm{E}$ & 14 & 0.053 \\
\hline 2 & Esperstedt & Natural inland & C Germany & $51^{\circ} 20.65^{\prime} \mathrm{N} / 11^{\circ} 09.66^{\prime} \mathrm{E}$ & 15 & 0.051 \\
\hline 3 & Artern & Natural inland & C Germany & $51^{\circ} 22.19^{\prime} \mathrm{N} / 11^{\circ} 17.00^{\prime} \mathrm{E}$ & 15 & 0.076 \\
\hline 4 & Buggingen & Anthropogenic inland & SW Germany & $47^{\circ} 51.55^{\prime} \mathrm{N} / 07^{\circ} 37.18^{\prime} \mathrm{E}$ & 15 & 0.076 \\
\hline 5 & Teutschenthal & Anthropogenic inland & C Germany & $51^{\circ} 27.94^{\prime} \mathrm{N} / 11^{\circ} 46.20^{\prime} \mathrm{E}$ & 14 & 0.082 \\
\hline 6 & Neuhof-Ellers & Anthropogenic inland & C Germany & $50^{\circ} 27.79^{\prime} \mathrm{N} / 09^{\circ} 35.81^{\prime} \mathrm{E}$ & 15 & 0.053 \\
\hline 7 & Hänigsen & Anthropogenic inland & C Germany & $52^{\circ} 29.59^{\prime} \mathrm{N} / 10^{\circ} 06.38^{\prime} \mathrm{E}$ & 15 & 0.084 \\
\hline 8 & Noordpolderzyl & Coast, North Sea & Netherlands & $53^{\circ} 26.15^{\prime} \mathrm{N} / 06^{\circ} 34.91^{\prime} \mathrm{E}$ & 15 & 0.143 \\
\hline 9 & Fährdorf (Poel) & Coast, Baltic Sea & Germany & $53^{\circ} 58.22^{\prime} \mathrm{N} / 11^{\circ} 28.55^{\prime} \mathrm{E}$ & 15 & 0.141 \\
\hline 10 & Krik Vig & Coast, North Sea & Denmark & $56^{\circ} 43.51^{\prime} \mathrm{N} / 08^{\circ} 15.02^{\prime} \mathrm{E}$ & 5 & 0.142 \\
\hline 11 & Aggersund & Coast, Limfjord & Denmark & $57^{\circ} 00.10^{\prime} \mathrm{N} / 09^{\circ} 17.31^{\prime} \mathrm{E}$ & 5 & 0.165 \\
\hline 12 & Jerup & Coast, Baltic Sea & Denmark & $57^{\circ} 32.67^{\prime} \mathrm{N} / 10^{\circ} 26.27^{\prime} \mathrm{E}$ & 5 & 0.146 \\
\hline 13 & Ambleteuse & Coast, English Channel & France & $50^{\circ} 48.35^{\prime} \mathrm{N} / 01^{\circ} 36.47^{\prime} \mathrm{E}$ & 10 & 0.113 \\
\hline 14 & Marina de Pisa & Coast, Mediterranean & Italy & $43^{\circ} 40.07^{\prime} \mathrm{N} / 10^{\circ} 16.48^{\prime} \mathrm{E}$ & 4 & 0.038 \\
\hline 15 & Palude de Tombolo & Coast, Mediterranean & Italy & $43^{\circ} 35.55^{\prime} \mathrm{N} / 10^{\circ} 17.55^{\prime} \mathrm{E}$ & 3 & 0.056 \\
\hline 16 & Lange Lacke & Natural inland & Austria & $47^{\circ} 45.97^{\prime} \mathrm{N} / 16^{\circ} 52.80^{\prime} \mathrm{E}$ & 5 & 0.047 \\
\hline 17 & Zicksee & Natural inland & Austria & $47^{\circ} 46.02^{\prime} \mathrm{N} / 16^{\circ} 46.77^{\prime} \mathrm{E}$ & 4 & 0.102 \\
\hline 18 & Gsigsee & Natural inland & Austria & $47^{\circ} 45.87^{\prime} \mathrm{N} / 16^{\circ} 50.39^{\prime} \mathrm{E}$ & 5 & 0.131 \\
\hline
\end{tabular}

$N$ number of individuals successfully analysed for nine AFLP primer combinations, C Germany Central Germany, SW Germany Southwest Germany 
Table 2 Primer combinations used for selective amplification. HindIII primers were fluorescence-labeled

\begin{tabular}{lcc}
\hline Primer combination & $\begin{array}{l}\text { Total no. of } \\
\text { characters }\end{array}$ & $\begin{array}{l}\text { No. of polymorphic } \\
\text { characters }\end{array}$ \\
\hline HindIII + ACA/MseI + AAC & 37 & 12 \\
HindIII + AGC/MseI + AAC & 17 & 9 \\
HindIII + AAG/MseI + CAA & 34 & 9 \\
HindIII + ACA/MseI + CGA & 13 & 10 \\
HindIII + ACA/MseI + CAA & 41 & 17 \\
HindIII + ACC/MseI + CTA & 15 & 5 \\
HindIII + ACC/MseI + AAG & 21 & 11 \\
HindIII + ACA/MseI + CTA & 30 & 16 \\
HindIII + AAC/MseI + AAG & 34 & 29 \\
Total & 242 & 118 \\
\hline
\end{tabular}

(Li-Cor 4200 IR $^{2}$; Li-Cor Inc., Lincoln, Nebr.). Gel images were stored electronically.

Data analysis

AFLP banding patterns were evaluated manually by assigning to each band in a particular position one of three states: present (1), absent (0) or ambiguous (4). Bands that were unequivocally interpretable as either present or absent were assembled to generate a binary (1/0) matrix. Fragments of equal size were generally considered as being homologous to each other, irrespective of their relative intensities. All bands were assumed to represent independent loci. Randomly chosen samples were used to test the reproducibility of each of the steps of the AFLP procedure including band scoring.

The computer package ArLequin ver 3.1 (Excoffier and Schneider 2006) was used to estimate average gene diversity values over all loci. An analysis of variance (ANOVA, post-hoc: Tukey test) was performed using PRISM 5 for Windows, ver. 5.01 (1992-2007 trial, Graphpad Software, Inc.) to compare the results obtained for different types of salt habitat: (i) German natural and (ii) anthropogenic inland salt sites, (iii) natural inland habitats in Austria, coastal salt sites of the (iv) North and (v) Baltic Seas as well as (vi) the English Channel and (vii) the Mediterranean Sea (see. Fig. 1, Table 1). The NTSYSpc ver. 2.1 program package (Rohlf 2000) was used to perform principal coordinate analyses (PCoA) based on a square-root transformed distance matrix calculated with the index of Bray and Curtis (1957). A Nei-Li distance matrix (1979) was generated using Treecon ver. 1.3b (Van de Peer and De Wachter 1994), and was exported to SpLitsTreE ver. 4.9.1 (Huson and Bryant 2006). The latter program allows the user to explore the relationships indicated by a distance matrix using the NeighborNet algorithm (Bryant and Moulton 2004).
A Bayesian clustering approach implemented in the program STRUCTURE ver. 2.2 (Pritchard et al. 2007) was utilized to infer population structure. According to the dominant character of AFLP markers, the second allele of all markers was entered as missing, and each band was thus treated as a haploid allele. An admixture model was applied, and the most likely number of populations or groups of populations $(K)$ was estimated with 10 replicates each for $K=1$ to $K=15$ using $5 \times 10^{4}$ iterations, with a burn-in period of $10^{4}$ iterations. The best estimated $K$ was defined by the model giving the highest probability ( $\mathrm{Ln}$ $\mathrm{P}(\mathrm{D}))$ with lowest deviation. The number of estimated populations or groups of populations $(K)$ does not necessarily equal the number of real populations or groups of them.

To assess the extent of genetic differentiation among populations or assumed groups of populations, pairwise distances ( $\Phi_{\mathrm{ST}}$ values) were calculated according to Weir and Cockerham (1984), and hierarchical analyses of molecular variance (AMOVA, Excoffier et al. 1992) were carried out in ARLEQUin (ver 3.1, Excoffier and Schneider 2006). Correlations between genetic distances (pairwise $\Phi_{\mathrm{ST}}$ values) and geographical distances between populations were assessed with a Mantel test (Mantel 1967), also using ARLequin (ver. 3.1). All significance levels were calculated on the basis of 1000 permutations.

\section{Results}

Nine primer combinations yielded in 242 unequivocally scorable und reproducible AFLP bands (13-41 per primer pair) among 179 individuals of $S$. media from 18 European populations. Sizes of the scored fragments ranged between 61 and $480 \mathrm{bp}$. Two band positions were excluded from the analysis due to ambiguous or missing data in more than $10 \%$ of all samples. Only 118 bands (49\%) were polymorphic, and were included in the analysis (Table 2).

Genetic diversity within populations was generally low and ranged from 0.038 for the Mediterranean population Marina de Pisa (Italy) to 0.165 for Aggersund from the Danish North Sea coast (Table 1). Coastal populations of the North Sea and the Baltic Sea including the English Channel showed significantly higher values $(0.113-0.165)$ as compared to the anthropogenic and natural inland salt sites (0.047-0.131, ANOVA: $P<0.05)$. Low values were also found in the two Italian populations (0.038 and 0.056). No significant difference was observed between natural and anthropogenic inland populations $(P>0.05)$, but genetic diversity values tended to be slightly higher in the Austrian populations as compared to the German inland populations.

In the PCoA (Fig. 2), the first two axes explained approximately $45 \%$ of the overall genetic variability. Four 


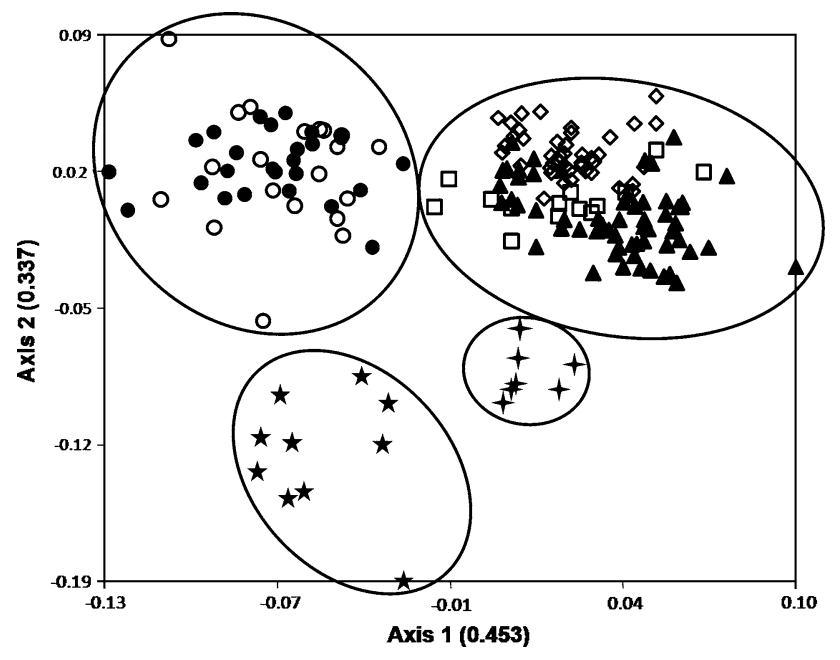

Fig. 2 Principal coordinate analysis (PCoA) of 179 individual $S$. media plants based on AFLP data. The first two axes together account for $45 \%$ of the overall variability. Symbols refer to the geographic origin and/or type of habitat (see Fig. 1). Eigenvalues are given in parentheses

distinct groups were recognized that partially reflect the geographical origin and/or type of habitat. The first axis (25.6\%) clearly separated the Central European coastal populations (Germany, the Netherlands, Denmark) from those of the inland salt sites (Germany, Austria) as well as the two Italian coastal populations from the French one. The second axis (19.1\%) separated all Central European populations from those of Italy and France. These groupings of populations were corroborated by the NeighborNet analysis, which revealed some additional details (see Online Resource, ESM 1). Thus, populations from coastal and inland salt sites are clearly separated from each other, and the latter are divided into three subclusters corresponding to plants from (1) Austria and Southwest Germany (Buggingen), (2) anthropogenic salt sites from Central Germany, and (3) natural inland salt sites from Central Germany, with only a few outliers. The coastal individuals form groups that correspond quite well to their geographic origin. One cluster comprises all individuals from the German Baltic Sea coast and the Dutch North Sea coast, a second one combines all individuals from Denmark, and a third and fourth cluster those from France and Italy, respectively. It should be noted, however, that the large number of parallelograms within the NeighborNet graph indicates a considerable extent of conflicting signals for all groupings.

The Bayesian analysis of population structure detected seven groups $(K=7)$ when choosing the highest absolute probability (Ln P(D)). The lowest standard deviation calculated from 10 iterations for each $K$ was nevertheless found for $K=5$ (see Online Resource, ESM 2). The analysis based on $\mathrm{K}=5$ revealed five groups, comprising all inland populations from Central Germany (1-3 and 5-7 in Table 1), the single anthropogenic inland population from Southwest Germany (Buggingen) plus the three Austrian inland populations (4, 16-18), the coastal populations from Germany and the Netherlands (8 and 9), the coastal populations from Denmark (10-12), and those from France and Italy (13-15), respectively. If $K=7$ is chosen, basically the same groups were obtained as suggested by the NeighborNet analysis (see Online Resources, ESM 1 and ESM 2).

The AFLP data were also subjected to several AMOVAs, assuming either no grouping among populations or five or seven groups of populations as suggested by the STRUCTURE analyses (Table 3). Under all three assumptions, a considerable percentage of the total variation occurred at the level of populations and/or groups. For example, the AMOVA based on $K=5$ explained almost one-third $(31 \%)$ of the total variation among five groups of populations, and the AMOVA based on $K=7$ explained $38 \%$ of the total variation among seven groups. When no grouping was assumed, the percentages of within-population variability and among-population variability were almost balanced (49 vs. $51 \%$, Table 3). Genetic differentiation between populations as indicated by pairwise $\Phi_{\mathrm{ST}}$ values ranged from 0.070 (populations 17 and $18,4.5 \mathrm{~km}$ apart) to 0.818 (populations 14 and 16, $686 \mathrm{~km}$ apart; Table 4, details not shown). Differentiation values $<0.3$ were assessed only in 14 out of 171 comparisons. Mean pairwise $\Phi_{\mathrm{ST}}$ values between groups of populations ranged from 0.300 to 0.470 (for $\mathrm{K}=5$ ) and from 0.239 to 0.676 (for $\mathrm{K}=7$, Table 4). The lowest differentiation between groups $\left(\Phi_{\mathrm{ST}}=0.239\right)$ was observed by comparing the coastal populations of Germany/the Netherlands with those of Denmark. The Mantel test yielded a correlation coefficient of $r=0.413$ ( $P \leq 0.001$, data not shown), suggesting a significant correlation of genetic (mean pairwise $\Phi_{\mathrm{ST}}$ values) and geographic distances among populations.

\section{Discussion}

Genetic diversity and genetic structure of inland versus coastal populations

Genetic variation among $S$. media plants sampled across a relatively large geographic area (Fig. 1) proved to be low, as was illustrated by a maximum within-population gene diversity value of 0.143 (Table 1) and a large proportion (almost 50\%) of AFLP bands that were monomorphic across all samples (Table 2). Low to moderate values of average gene diversity within populations were also found in other marker-based studies on Central European halophytes, such as Suaeda maritima (AFLP: 0.011-0.175, 
Table 3 Analysis of molecular variance (AMOVA) based on 118 AFLP markers for 179 individuals in 18 populations of $S$. media, either assuming no grouping or assuming two different partitions of populations ( $* P<0.001$ ) based on the STRUCtURE analysis

\begin{tabular}{lrrcll}
\hline Source of variation & df & $\begin{array}{l}\text { Sum of } \\
\text { Squares }\end{array}$ & $\begin{array}{l}\text { Variance } \\
\text { components }\end{array}$ & $\begin{array}{l}\text { Percentage of } \\
\text { variation }\end{array}$ & $\Phi$-Statistics \\
\hline Without grouping & & & & & \\
$\quad$ Among populations & 17 & 1029.2 & 5.6 & 51.5 & $0.515^{*}$ \\
Within populations & 161 & 856.1 & 5.3 & 48.5 & - \\
$\quad 178$ & 1885.3 & 11.0 & - & - \\
Total & & & & & $0.311^{*}$ \\
K 5 & 4 & 592.2 & 3.7 & 31.1 & $0.353^{*}$ \\
Among groups & 13 & 437.0 & 2.9 & 24.3 & $0.554^{*}$ \\
Among populations within groups & 161 & 856.1 & 5.3 & 44.6 & - \\
Within populations & 178 & 1885.3 & 11.9 & - & $0.385^{*}$ \\
Total & & & & & $0.250^{*}$ \\
$K=7$ & 6 & 783.2 & 4.4 & 38.5 & $0.538^{*}$ \\
Among groups & 11 & 246.0 & 1.8 & 15.4 & - \\
Among populations within groups & 161 & 856.1 & 5.3 & 46.2 & - \\
$\quad$ Within populations & 178 & 1885.3 & 11.5 & &
\end{tabular}

Prinz et al. 2009), Calystegia soldanella (AFLP: 0.1030.174, Arafeh and Kadereit 2006), Salicornia europaea (RAPD: 0.157-0.245) and Aster tripolium (RAPD: 0.1810.297, Krüger et al. 2002).

Furthermore, a considerable degree of genetic differentiation between populations and between groups of populations was revealed by the AMOVAs (Table 3) as well as by pairwise $\Phi_{\mathrm{ST}}$ values (Table 4 ). Reduced levels of genetic variability in conjunction with a high degree of genetic differentiation among populations are typically found in plant species with a selfing or mixed mating system (Hamrick and Godt 1996; Reed and Frankham 2003; Nybom 2004; Hensen et al. 2009), suggesting that selfing could be the main reproduction mode of $S$. media. Alternatively, the observed patterns could also be a consequence of genetic bottlenecks caused by repeated postglacial colonization and retreat, as was reported for several halophytes that had been analyzed across their entire European range (Kadereit et al. 2005; Jakob et al. 2007).

With a few exceptions (see below), inland populations of $S$. media were less diverse than coastal populations (Table 1). This could be explained by various factors, including limited gene flow to isolated inland areas, small population size, genetic bottlenecks and founder effects. Coastal habitats are usually linear, but also large and continuous, in strong contrast to the small, fragmented and

Table 4 Mean pairwise genetic distances $\left(\Phi_{\mathrm{ST}}\right)$ between groups of $S$. media populations defined by STRUCTURE for $K=5$ and $K=7$ $(* P<0.001)$

\begin{tabular}{|c|c|c|c|c|c|c|c|}
\hline \multirow{2}{*}{$\frac{K=5}{\text { Inland }(\mathrm{CG})}$} & \multicolumn{2}{|l|}{ Inland (CG) } & Coast (G/NL) & Coast (D) & \multicolumn{2}{|c|}{ Coast (F/I) } & \multirow{2}{*}{$\begin{array}{l}\text { Inland (SWG/A) } \\
-\end{array}$} \\
\hline & - & - & & - & - & & \\
\hline Coast (G/NL) & $0.397 *$ & - & & - & - & & - \\
\hline Coast (D) & $0.442 *$ & $0.239 *$ & & - & - & & - \\
\hline Coast (F/I) & $0.470^{*}$ & $0.385^{*}$ & & $0.357 *$ & - & & - \\
\hline Inland (SWG/A) & $0.300 *$ & $0.387 *$ & & $0.346^{*}$ & 0.447 & & - \\
\hline$K=7$ & Nat inland (CG) & Ant inland (CG) & Coast $(\mathrm{G} / \mathrm{Nl})$ & Coast (D) & Coast $(\mathrm{F})$ & Coast (I) & Inland (SWG/A) \\
\hline Nat inland (CG) & - & - & - & - & - & - & - \\
\hline Ant inland (CG) & $0.332 *$ & - & - & - & - & - & - \\
\hline Coast (G/NL) & $0.418^{*}$ & $0.462^{*}$ & - & - & - & - & - \\
\hline Coast (D) & $0.487 *$ & $0.493 *$ & $0.239 *$ & - & - & - & - \\
\hline Coast $(\mathrm{F})$ & $0.650 *$ & $0.588^{*}$ & $0.443^{*}$ & $0.412 *$ & - & - & - \\
\hline Coast (I) & $0.676^{*}$ & $0.622 *$ & $0.535^{*}$ & $0.532 *$ & $0.623^{*}$ & - & - \\
\hline Inland (SWG/A) & $0.415^{*}$ & $0.335^{*}$ & $0.387^{*}$ & $0.346^{*}$ & $0.543 *$ & $0.602 *$ & - \\
\hline
\end{tabular}

$G$ Germany, $C G$ Central Germany, $S W G$ Southwest Germany, $N L$ the Netherlands, $D$ Denmark, $F$ France, $I$ Italy, $A$ Austria, nat natural, ant anthropogenic 
isolated inland salt sites that are more likely the subject of genetic drift (Van Rossum et al. 2004; Vandepitte et al. 2007). Accordingly, the lowest pairwise $\Phi_{\text {ST }}$ values were observed among the coastal populations of the North Sea and the Baltic Sea (0.239, Table 4$)$. The moderate gene flow along the coastline is likely due to the high dispersability of $S$. media seeds by wind, water, and especially waterfowl (Hegi 1965; Huiskes et al. 1995), whereas gene flow among the highly fragmented inland populations seems to be much less effective $\left(\Phi_{\mathrm{ST}}>0.3\right.$ in all pairwise comparisons). We assume that genetic diversity within the presumably old, but small halophyte populations of natural inland salt sites could have been decreased by genetic bottlenecks, whereas the relatively young populations in anthropogenic inland salt habitats might have experienced founder effects. Both types of events are often accompanied by a negative impact on viability and fitness (e.g., England et al. 2002; Vergeer et al. 2003; Hensen and Oberprieler 2005). We currently investigate the relative fitness of inland versus coastal individuals by transplantation and common garden experiments, but no conclusive results have been obtained yet. No significant differences in genetic diversity were found by comparing natural versus anthropogenic inland populations in Central Germany (Table 1). Similar observations were previously reported for Central European inland populations of three other halophytic species, i.e., Suaeda maritima (Prinz et al. 2009), Salicornia ramosissima and Aster tripolium (Krüger et al. 2002).

A somewhat exceptional behavior was shown by the two populations from the Mediterranean coast of Italy, which exhibited very low diversity values (0.038 and 0.056, Table 1). While these results must be treated with caution due to small sample sizes, they could also be the result of the scarcity and insular distribution of suitable habitats for $S$. media along this coastal region. The highest diversity values among any of the inland populations were found in two of the three investigated populations from the Neusiedler See in Austria (0.102 and 0.131; Table 1). This observation was even more pronounced in an ongoing study based on microsatellites (K Prinz, unpublished), and could perhaps be explained by the geographical proximity of these sites to the Pannonian lowland that offers suitable habitats with high connectivity for continentally distributed halophytic species.

All types of analyses indicate a marked correlation between genetic and geographic distances. Thus, coastal populations from France, Italy, Denmark and Germany/the Netherlands were clearly separated from each other (and from the inland populations) in the NeighborNet tree (Online Resource, ESM 1) and in the Bayesian analyses (Online Resource, ESM 2). The only notable exception are the populations from the German Baltic Sea coast and from the Dutch North Sea coast, which together form a closely related genetic group, despite a considerable geographic distance. This may indicate the strong gene flow mainly by birds among the continuous salt meadows along the Central European coastline. The isolation-by-distance observed in most of the comparisons may have historic causes. Thus, many halophytic species probably survived the glaciations of the Pleistocene in refugia along the Mediterranean coast, and our Italian $S$. media plants could well be derived from such refugia (Clausing et al. 2000; Kadereit et al. 2005; Arafeh and Kadereit 2006; Lambracht et al. 2007). However, a more dense sampling strategy will have to be applied for reconstructing the postglacial history of S. media.

\section{Colonization of anthropogenic habitats}

Still little is known about the general patterns of colonization of the vicinity of potash mining dumps, and only few population genetic investigations have yet been dedicated to inland halophytes of Central Germany (Krüger et al. 2002; Brock et al. 2007; Lambracht et al. 2007; Prinz et al. 2009). Possible origins of the colonizers were either not examined, or remained elusive in any of these studies, and this failure was often attributed to an inadequate sampling. In the present study, mean genetic distances between inland and coastal populations of Central Europe were clearly higher than those between natural and anthropogenic inland salt sites. Moreover, individuals from Central German natural and anthropogenic salt sites grouped closely together in the NeighborNet tree (see Online Resource, ESM 1). Taken together, these observations suggest that the recently founded anthropogenic $S$. media populations in Central Germany could have originated from natural inland salt sites rather than from the coasts. Our results on the genetic structure of $S$. media are in concordance with Garve (1999a), who postulated colonization of German anthropogenic salt sites from east to west, based on sporadic records of various halophytic species in the 1960s and 1970s (John and Zenker 1978; Rauschert 1979). Spergularia media has occasionally been recorded from Central Germany since at least the 1960s, but the almost "explosive" colonization of potash mining dumps by the species only occurred in the 1990s (Garve and Garve 2000; John 2000).

The colonization history seems to have been different in southern Germany and the Alsace. Spergularia media has been recorded from the vicinity of potash mining dumps in the Alsace since the mid-1950 s and from Buggingen (SW Germany) since 1978 (Garve and Garve 2000). The results from the NeighborNet and STRUCTURE analyses indicate a close relationship between the populations from Austria and the Alsace, suggesting colonization from Austria. As 
already mentioned by Aellen (1958), the colonization of the anthropogenic salt habitats of the Alsatian region by halophytes could be explained by transcontinental bird migration, whereas additional kinds of vectors such as wind or humans may have played a more important role for the Central German salt sites (Guder et al. 1998).

\section{Conclusions}

The observed patterns of diversity and differentiation among inland populations of $S$. media are best explained by the isolated nature of suitable inland salt habitats with concomitant reduction of gene flow to and among these sites. Furthermore, we found indications that the colonization of anthropogenic salt sites by $S$. media originated from natural inland habitats. Further investigations on the dispersal ecology of halophytes as well as the use of more variable molecular markers (e.g., nuclear microsatellites) in combination with an extended sampling design will be required to get a more general view of the striking colonization history of these sites.

Acknowledgments We would like to thank the Amt der Burgenländischen Landesregierung, Landesverwaltungsamt Sachsen-Anhalt, Thüringer Landesverwaltungsamt, and $K+S$ Aktiengesellschaft for the permission to collect leaves of $S$. media in protected and/or privately owned areas. We also thank Maja Rother, Peggy Paschke and Alexander Meier for help in the laboratory, and Dr. Daniela Guicking, Tina Wöhrmann, Meike Poppenhäger and Henrik von Wehrden for help with data analysis and manifold critical comments on this manuscript.

Open Access This article is distributed under the terms of the Creative Commons Attribution Noncommercial License which permits any noncommercial use, distribution, and reproduction in any medium, provided the original author(s) and source are credited.

\section{References}

Aellen E (1958) Beitrag zur Kenntnis der Ausbreitung binnenländischer Halophyten durch Vögel. Bauhinia 1:5-89

Arafeh R, Kadereit JW (2006) Long-distance seed dispersal, clone longevity and lack of phylogeographical structure in the European distributional range of the coastal Calystegia soldanella (L.) R. Br. (Convolvulaceae). J Biogeogr 33:1461-1469. doi:10.1111/j.1365-2699.2006.01512.x

Bänfer G, Fiala B, Weising K (2004) AFLP analysis of phylogenetic relationships among myrmecophytic species of Macaranga (Euphorbiaceae) and their allies. Plant Syst Evol 249:213-231. doi:10.1007/s00606-004-0219-4

Brandes D (1999) Flora und Vegetation salzbeeinflußter Habitate im Binnenland-eine Einführung. Braunschweiger Geobot Arb 6: 7-12

Bray JR, Curtis JT (1957) An ordination of the upland forest communities of southern Wisconsin. Ecol Monogr 27:325-349
Brock J, Aboling S, Stelzer R, Esch E, Papenbrock J (2007) Genetic variation among different populations of Aster tripolium grown on naturally and anthropogenic salt-contaminated habitats: implications for conservation strategies. J Plant Res 120:99112. doi:10.1007/s10265-006-0030-7

Bryant D, Moulton V (2004) Neighbor-Net: an agglomerative method for the construction of phylogenetic networks. Mol Biol Evol 21:255-265. doi:10.1093/molbev/msh018

Clausing G, Vickers K, Kadereit JW (2000) Historical biogeography in a linear system: genetic variation of sea rocket (Cakile maritima) and sea holly (Eryngium maritimum) along European coasts. Mol Ecol 9:1823-1833. doi:10.1046/j.1365-294x.2000. 01083.x

Doyle JJ, Doyle JL (1987) A rapid DNA isolation procedure for small amount of fresh leaf issue. Phytochem Bull 19:11-15

England PR, Usher AV, Whelan RJ, Ayre DJ (2002) Microsatellite diversity and genetic structure of fragmented populations of the rare, fire-dependent shrub Grevillea macleayana. Mol Ecol 11:967-977. doi:10.1046/j.1365-294X.2002.01500.x

Excoffier LGL, Schneider S (2006) ARLEQUIN ver 3.1: an integrated software package for population genetics data analysis. Computational and Molecular Population Genetics Lab (CMPG), University of Berne, Switzerland

Excoffier L, Smouse PE, Quattro JM (1992) Analysis of molecular variance inferred from metric distances among DNA haplotypes: applications to human mitochondrial DNA restriction data. Genetics 131:479-491

Garve E (1999a) Neu aufgetretene Blütenpflanzen an salzhaltigen Rückstandshalden in Niedersachsen. Braunschweiger Geobot Arb 6:171-191

Garve E (1999b) Zur Flora der Kalihalden in der Region um Hannover. Ber Naturhist Ges Hann 141:197-218

Garve E, Garve V (2000) Halophyten an Kalihalden in Deutschland und Frankreich (Elsass). Tuexenia 20:375-417

Guder C, Evers C, Brandes D (1998) Kalihalden als Modellobjekte der kleinräumigen Florendynamik dargestellt an Untersuchungen im nördlichen Harzvorland. Braunschweiger Naturkundl Schr 5:641-665

Hamrick JL, Godt MJW (1996) Effects of life history traits on genetic diversity in plant species. Phil Trans R Soc Lond B 351:12911298. doi: $10.1098 /$ rstb. 1996.0112

Hegi G (1965) Illustrierte Flora von Mitteleuropa, Bd. 3. Lehmann`s Verlag, München

Hensen I, Oberprieler C (2005) Effects of population size on genetic diversity and seed production in the rare Dictamnus albus (Rutaceae) in central Germany. Conserv Genet 6:63-73. doi: 10.1007/s10592-004-7745-6

Hensen I, Kilian C, Wagner V, Durka W, Pusch J, Wesche K (2009) Low genetic variability and strong differentiation among isolated populations of the rare steppe grass Stipa capillata L. in central Europe. Plant Biol (in press). doi:10.1111/j.1438-8677. 2009.00227.x

Huiskes AHL, Koutstaal BP, Herman PMJ, Beeftink WG, Markusse MM, De Munck W (1995) Seed dispersal of halophytes in tidal salt marshes. J Ecol 83:559-567

Huson DH, Bryant D (2006) Application of phylogenetic networks in evolutionary studies. Mol Biol Evol 23:254-267. doi: 10.1093/molbev/msj030

Jakob SS, Ihlow A, Blattner FR (2007) Combined ecological niche modelling and molecular phylogeography revealed the evolutionary history of Hordeum marinum (Poaceae)—niche differentiation, loss of genetic diversity, and speciation in Mediterranean Quaternary refugia. Mol Ecol 16:1713-1727. doi: 10.1111/j.1365-294X.2007.03228.x

John H (2000) Zur Ausbreitung von Halophyten und salztoleranten Pflanzen in der Umgebung von Kali-Rückstandshalden am 
Beispiel des FND "Salzstelle bei Teutschenthal-Bahnhof" (Saalkreis). Mitt florist Kart Sachsen-Anhalt 5:175-197

John H, Zenker E (1978) Funde und Beobachtungen von höheren Pflanzen im südlichen Sachsen-Anhalt. Mitt florist Kart SachsenAnhalt 1:49-57

Kadereit JW, Arafeh R, Somogyi G, Westberg E (2005) Terrestrial growth and marine dispersal? Comparative phylogeography of five coastal plant species at a European scale. Taxon 54:861-876

Krüger AM, Hellwig FH, Oberprieler C (2002) Genetic diversity in natural and anthropogenic inland populations of salt-tolerant plants: random amplified polymorphic DNA analyses of Aster tripolium L. (Compositae) and Salicornia ramosissima woods (Chenopodiaceae). Mol Ecol 11:1647-1655. doi:10.1046/ j.1365-294X.2002.01562.x

Lambracht E, Westberg E, Kadereit JW (2007) Phylogeographic evidence for the postglacial colonization of the North and Baltic Sea coasts from inland glacial refugia by Triglochin maritima $\mathrm{L}$. Flora 202:79-88. doi:10.1016/j.flora.2006.05.001

Lienert J (2004) Habitat fragmentation effects on fitness of plant populations-a review. J Nat Conserv 12:53-72. doi:10.1016/ j.jnc.2003.07.002

Mantel NA (1967) The detection of disease clustering and generalized regression approach. Can Res 27:209-220

Nei M, Li W-H (1979) Mathematical model for studying genetic variation in terms of restriction endonucleases. Proc Natl Acad Sci USA 76:5269-5273

Novak SJ, Mack RN (2005) Genetic bottlenecks in alien plant species: influence of mating systems and introduction dynamics. In: Sax DF, Stachowitz JJ, Gaines SD (eds) Species invasions. Insights into ecology, evolution, and biogeography. Sinauer Associates Inc, Sunderland

Nybom H (2004) Comparison of different nuclear DNA markers for estimating intraspecific genetic diversity in plants. Mol Ecol 13:1143-1155. doi:10.1111/j.1365-294X.2004.02141.x

Plieninger W (1992) Einige bemerkenswerte floristische Funde in Baden-Württemberg. Flor Rundbr 26:11-20

Prinz K, Weising K, Hensen I (2009) Genetic structure of coastal and inland populations of the annual halophyte Suaeda maritima (L.) DUMORT. In Central Europe, inferred from amplified fragment length polymorphism (AFLP) markers. Plant Biol 11:812-820. doi:10.1111/j.1438-8677.2008.00178.x

Pritchard JK, Wen X, Falush D (2007) Documentation for Structure software: Version 2.2. Department for Statistics, University of Oxford, Oxford
Rauschert S (1979) Zur Flora des Bezirks Magdeburg (4. Beitrag). Mitt florist Kart Halle 5:53-56

Reed DH, Frankham R (2003) Correlation between fitness and genetic diversity. Conserv Biol 17:230-237. doi:10.1046/j.1523-1739. 2003.01236.x

Rogstad SH (1992) Saturated NaCl-CTAB solution as a means of field preservation of leaves for DNA analyses. Taxon 41:701708

Rohlf FJ (2000) NTSYSpc: numerical Taxonomy and Multivariate Analysis System, Version 2.1. Applied Biostatistic Inc., Port Jefferson

Simon C (1958) Eine Halophytenflora am Oberrhein. Bauhinia $1: 144-150$

Van de Peer Y, De Wachter R (1994) TREECON for Windows: a software package for the construction and drawing of evolutionary trees for the Microsoft Windows environment. Comput Appl Biosci 10:569-570. doi:10.1093/bioinformatics/10.5.569

Van Rossum F, Campos de Sousa S, Triest L (2004) Genetic consequences of habitat fragmentation in an agricultural landscape on the common Primula veris, and comparison with its rare congener, $P$. vulgaris. Conserv Genet 5:231-245. doi: 10.1023/B:COGE.0000030007.85492.70

Vandepitte K, Jacquemyn H, Roldán-Ruiz I, Honnay O (2007) Landscape genetics of the self-compatible forest herb Geum urbanum: effects of habitat age, fragmentation and local environment. Mol Ecol 16:4171-4179. doi:10.1111/ j.1365-294X.2007.03473.x

Vergeer P, Rengelink R, Copal A, Ouborg NJ (2003) The interacting effects of genetic variation, habitat quality and population size on performance of Succisa pratensis. J Ecol 91:18-26. doi: 10.1046/j.1365-2745.2003.00736.x

Vollrath H, Bönsel D (1995) Die jungen Salzstellen der Werra-Aue, ihre Entstehung und Besiedlung durch Halophyten. Beitr Naturkde Osthessen 27:13-68

Vos P, Hogers R, Bleeker M, Reijans M, Van de Lee T, Hornes M, Frijters A, Pot J, Peleman J, Kuiper M, Zabeau M (1995) AFLP: a new technique for DNA fingerprinting. Nucl Acids Res 23:4407-4414

Weir BS, Cockerham CC (1984) Estimating F-statistics for the analysis of population structure. Evolution 6:1358-1370

Westhus W, Fritzlar F, Pusch J, Van Elsen T, Andres C, Grossmann M, Pfützenreuter S, Sparmberg H, Barthel K-J (1997) Binnensalzstellen in Thüringen-Situation, Gefährdung und Schutz. Naturschutzreport 12. Thüringer Landesanstalt für Umwelt, Jena 